\title{
POTENTIAL TO USE BIO CHAR IN MERCURY REMOVAL FROM GOLD MINING TAILINGS WASTEWATER
}

\author{
Mercy M. Manyuchi ${ }^{1}$, Charles Mbohwa ${ }^{1}$ and Edison Muzenda ${ }^{2}$ \\ ${ }^{I}$ Department of Operations and Quality Management, \\ Faculty of Engineering and the Built Environment, \\ University of Johannesburg, South Africa \\ ${ }^{2}$ Department of Chemical Engineering Technology, \\ Faculty of Engineering and the Built Environment, \\ University of Johannesburg, South Africa \\ Department of Chemical, Materials and Metallurgical Engineering, \\ Faculty of Engineering and Technology, \\ Botswana International University of Science and Technology, P Bag 16, Palapye, Botswana
}

\begin{abstract}
This work evaluated the potential to use saw dust based bio char in the treatment of mercury contaminated gold tailings wastewater. A sample of saw dust was first pyrolysed to produce bio char at $250 \circ$ for 30 minutes. The bio char was then ground to particle size of $0.5 \mathrm{~mm}$ so as to enhance the bio adsorption properties as well as to increase the surface area. The bio char which had a surface area of $500-700 \mathrm{~m}^{2} / \mathrm{g}$ was put in contact with the wastewater for 40 hours noting the change in mercury content using AAS. The variation in mercury content was noted for changing $\mathrm{pH}$. of 4-8 and bio char loading of 2-6 g/L. Highest mercury removal of $>90 \%$ were noted at $\mathrm{pH}$. of 8 and bio char loading of $6 \mathrm{~g} / \mathrm{L}$. From the study it can be concluded that saw dust based bio char provides an adsorbent that can lower mercury content in gold tailings wastewater
\end{abstract}

\section{KEYWORDS}

Adsorption, Bio Adsorption, Gold Processing, Mercury, Tailings Wastewater

\section{INTRODUCTION}

Mercury is a heavy metal that is readily available and affordable and is widely used in the gold mining sector. Gold is processed through various stages which include: ore extraction, crushing, grinding, concentration, roasting, metal extraction, metal recovery and refining. The gold processing process using a lot of mercury $(\mathrm{Hg})$ as part of its amalgamation process (Figure 1). This mercury like any other heavy metal if disposed to water bodies or is in contact with the human body has potential to cause problems in the blood circulatory systems, kidney diseases and rheumatoid arthritis due to its toxicity and bio accumulative nature. Previous studies have reported that for every $\mathrm{kg}$ of gold that is produced, approximately $1.32 \mathrm{~kg}$ of mercury is lost to the environment (Matshusa et al., 2012). Tailings that are generated from the gold processing are high in mercury and have potential to result in groundwater contamination. 


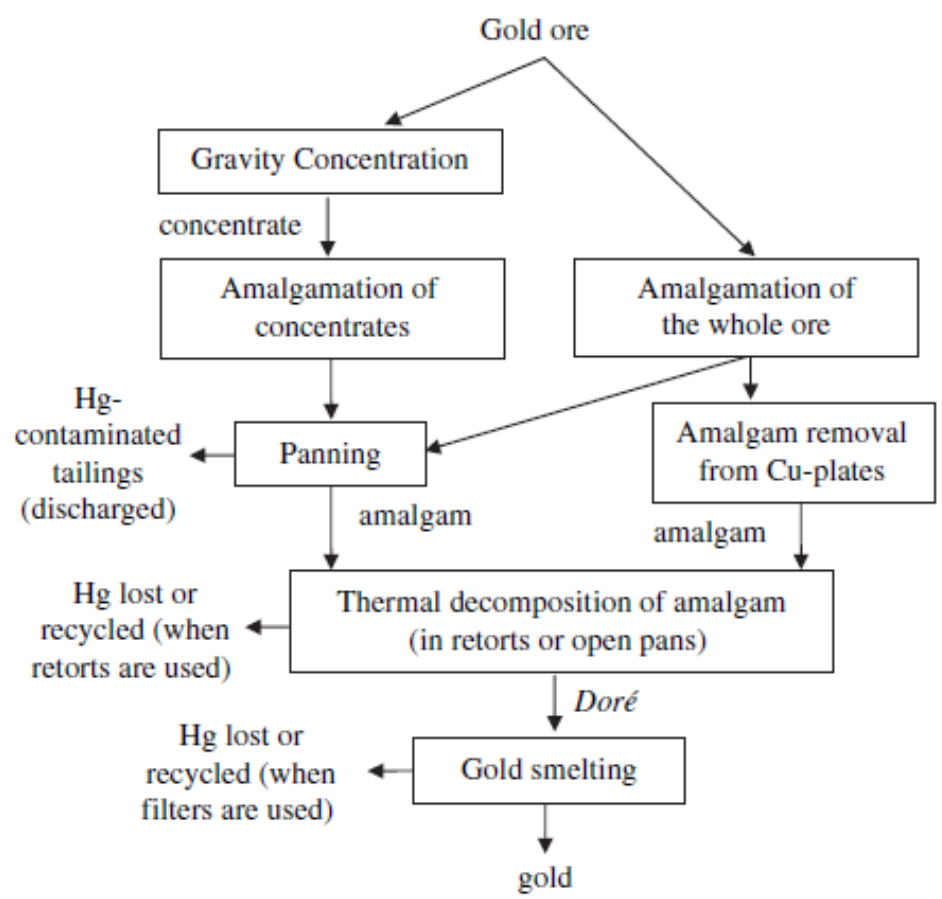

Figure 1. Uses of Mercury in Mercury Processing (Vega et al., 2006)

There is therefore a need to treat the gold mining process tailings dam water for removal of the mercury using low cost and low technology treatment technologies. The required mercury concentrations in wastewater effluent should be within $0.00003 \mathrm{mg} / \mathrm{L}$ (Babel and Kurniawan., 2003). On the other hand, biomass adsorbents from saw dust, cornstover, rice husk, bagasse among others have been reported to be excellent adsorption medias for heavy metals in wastewater (Khan et al., 2001; Wong et al., 2003; Arana et al., 2017). The heavy metals are removed from the wastewater through a process called bio adsorption whereby the biomass derived bio adsorbents are applied. Usually waste biomass is used as a raw material to produce bio char as a waste management initiative for mitigation of the release of climate change related gases such as carbon dioxide and methane (Vinodhini et al., 2010). This study therefore focussed on the assessment on the potential to use biomass adsorbents from saw dust for use in mercury removal from gold processing tailings wastewater.

\section{MATERIALS AND METHODS}

Saw dust from a local timber mill was used as the raw material for bio char preparation. A sample of $1 \mathrm{~kg}$ of the saw dust was pyrolysis in a lab scale pyrolysis reactor at a temperature of $250{ }^{\circ} \mathrm{C}$ for 30 minutes. The bio char was ground to finer particles to of $0.5 \mathrm{~mm}$ sieve allow it for use as a bio adsorbent. The bio char calorific value was determined using an adiabatic bomb calorimeter model C500. The bio char moisture content was measured by oven drying a $300 \mathrm{~g}$ sample for 24 hours at $105{ }^{\circ} \mathrm{C}$ in a Memmert oven. The bio char ash content was determined by heating a $1 \mathrm{~g}$ sample in the oven at $250{ }^{\circ} \mathrm{C}$ for 60 minutes until all the volatiles burnt off. The yield of the saw dust based bio char was calculated by dividing the amount of char produced against the amount of saw dust used before pyrolysis in accordance to Equation 1.

$$
\% \text { Biochar yield }=\left(\frac{\text { Mass of bio char }}{\text { Mass of saw dust }}\right) \times 100
$$


The surface area of the bio char was measured using the Brunauer-Emmett-Teller (BET) specific surface area technique. The adsorption efficiency of the mercury by the saw dust bio char was determined in accordance to Equation 2:

$$
\% S=\frac{\left(C_{O}-C_{K}\right)}{C_{O}} \times 100
$$

Where $C_{o}$ is the output concentration of mercury in milligrams per litre and $C_{k}$ is the concentration of mercury in milligrams per litre at a given time after adsorption.

Bio char loadings of 2-6 g/L of wastewater were used in a $2 \mathrm{~L}$ of gold tailings wastewater sample over a contact period of 40 hours. The gold mining tailings wastewater was characterized in accordance to APHA (2005). The wastewater was passed continuously in column of with $5 \mathrm{~cm}$ and height $100 \mathrm{~cm}$. The column was packed with quartz, sand and the bio char from the bottom in the ratio 1: 1: 2. The tailings wastewater was obtained from a local gold mining plant. The $\mathrm{pH}$ in the gold tailings wastewater was ranged between 4-8 using $0.1 \mathrm{M} \mathrm{NaOH}$ or $\mathrm{HNO}_{3}$ as required. The mercury concentration in the wastewater was determined using a Variant SpectraAA 300 AAS spectrophotometer. The pH was determined using a Hanna HI 990101 pH probe.

\section{RESULTS AND DISCUSSION}

\subsection{Bio Char Characteristics}

The characteristics of the bio char are given in Table 1 . The bio char had particle size ranging from $0.5 \mathrm{~mm}$ and surface area of $500-700 \mathrm{~m}^{2} / \mathrm{g}$. These properties allowed the bio char to be effectively used as a bio adsorbent for mercury removal in the wastewater.

Table 1. Physicochemical Characteristics of the Saw Dust Bio Char

\begin{tabular}{|c|c|}
\hline Property & Value \\
\hline Calorific value & $16.7-21.3 \mathrm{MJ} / \mathrm{kg}$ \\
\hline Moisture content & $3.1-4.2 \%$ \\
\hline Ash content & $11.8-17.1 \%$ \\
\hline Surface area & $500-700 \mathrm{~m}^{2} / \mathrm{g}$ \\
\hline Yield & $55-60 \%$ \\
\hline
\end{tabular}

\subsection{Effect of Bio Char on the Various Wastewater Parameters}

\subsubsection{Characteristics of the Wastewater}

The characteristics of the gold wastewater tailings is shown in Table 2. The wastewater had an average mercury content ranging from $0.05-0.07 \mathrm{mg} / \mathrm{L}$. 
Table 2. Characteristics of the Gold Wastewater

\begin{tabular}{|l|l|}
\hline Property & Value \\
\hline Temperature & $26-28 \circ \mathrm{C}$ \\
\hline DO & $1.8-6.2 \mathrm{mg} / \mathrm{L}$ \\
\hline $\mathrm{pH}$ & $8.1-8.4$ \\
\hline Turbidity & $1.4-5.3 \mathrm{NTU}$ \\
\hline TDS & $894-1348 \mathrm{mg} / \mathrm{L}$ \\
\hline TSS & $38.9-88.4 \mathrm{mg} / \mathrm{L}$ \\
\hline Cyanide & $7.4-11.8 \mathrm{mg} / \mathrm{L}$ \\
\hline As & $3.6-4.1 \mathrm{mg} / \mathrm{L}$ \\
\hline Fe & $20.2-24.9 \mathrm{mg} / \mathrm{L}$ \\
\hline COD & $88.9-150.6 \mathrm{mg} / \mathrm{L}$ \\
\hline
\end{tabular}

\subsubsection{Effect of $\mathrm{pH}$}

The mercury content decreased with increase in retention time at a bio char loading of $6 \mathrm{~g} / \mathrm{L}$ for all the various $\mathrm{pH}$ ranging from $\mathrm{pH} 4-\mathrm{pH} 6$ (Figure 2). Lowest mercury content of less than $0.01 \mathrm{mg} / \mathrm{L}$ were achieved at $\mathrm{pH}$ of 6 (Figure 2). During the process of bio adsorption, the $\mathrm{pH}$ has an effect on the metal ion solubility and the total charge of the bio adsorbent, highly acidic media affects the competitive ability of hydrogen ions hence low bio adsorption efficiency. The same trends in $\mathrm{pH}$ reduction were reported from previous studies by Kumar et al. (2011) and Tripath and Ranjan (2015).

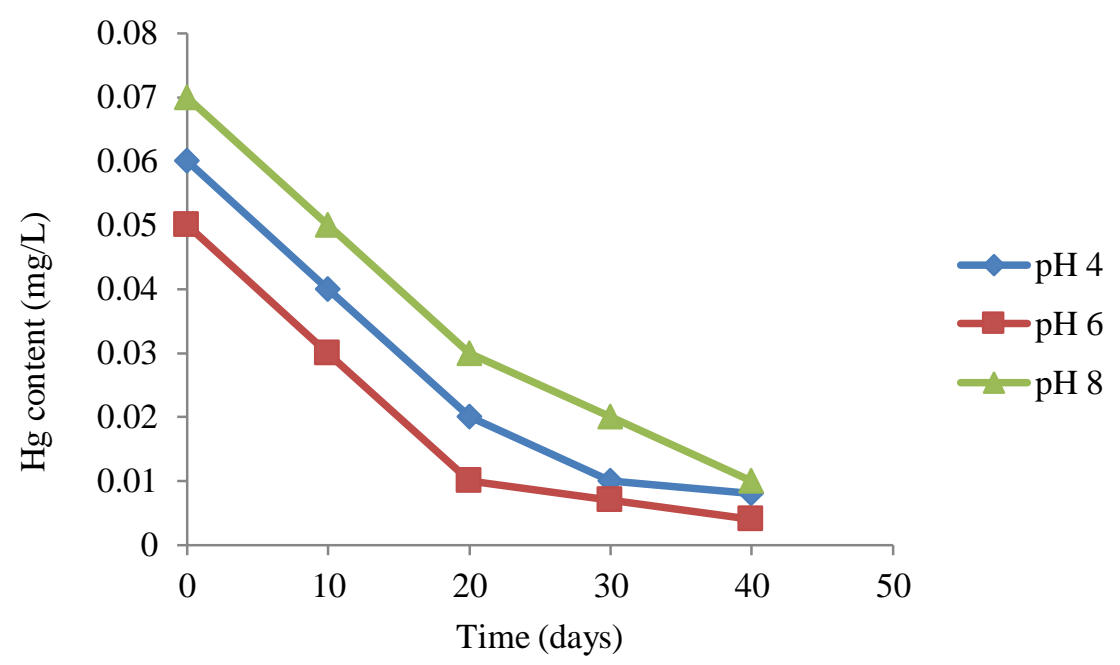

Figure 2. Effect of Varying $\mathrm{pH}$ on Mercury Content at Bio Char Loading of $6 \mathrm{~g} / \mathrm{L}$

\subsubsection{Adsorption Efficiency at Varying pH}

The adsorption efficiency was calculated in accordance of Equation 1. The adsorption efficiency decreased with increase in adsorption time (Figure 3). The decrease with increase in time was attributed to the clogging of the bio char as the adsorption process time increased. The lowest adsorption efficiency was for $\mathrm{pH}$ of 4 which was as low as $20 \%$ (Figure 3 ). Low $\mathrm{pH}$ of the tailings wastewater makes the treatment using bio char effective and sustainable. 


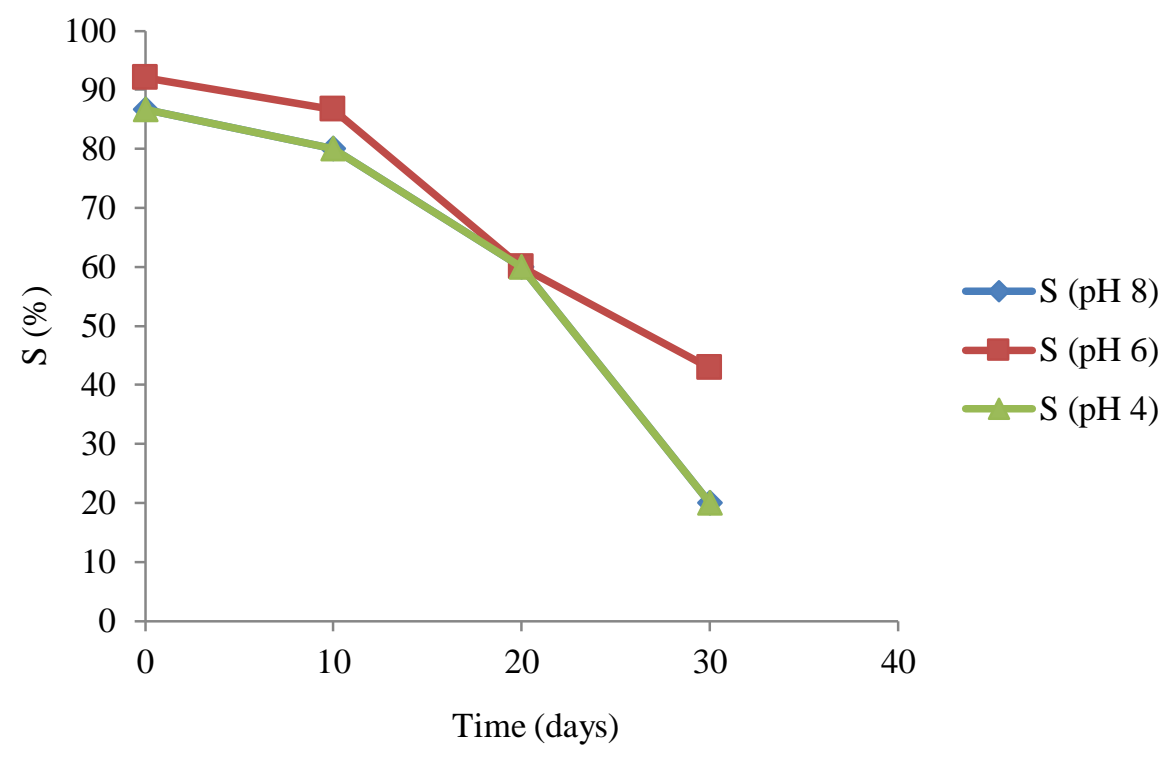

Figure 3. Adsorption Removal Efficiency at Varying $\mathrm{pH}$ and Bio Char Loading of $6 \mathrm{~g} / \mathrm{L}$

\subsubsection{Effect of varying Bio Char Concentration}

The mercury content decreased significantly with increase in the adsorption time to 40 hours with a bio char loading of $6 \mathrm{~g} / \mathrm{L}$ having the highest removal to up to $0.004 \mathrm{mg} / \mathrm{L}$ of mercury (Figure 4). Biomass derived bio adsorbents provide the binding sites for the adsorption process to take place during wastewater treatment (Gupta et al., 2010; Beesly et al., 2015). The higher the bio char loading, the many the sites available binding hence the effective mercury removal at loadings of $6 \mathrm{~g} / \mathrm{L}$.

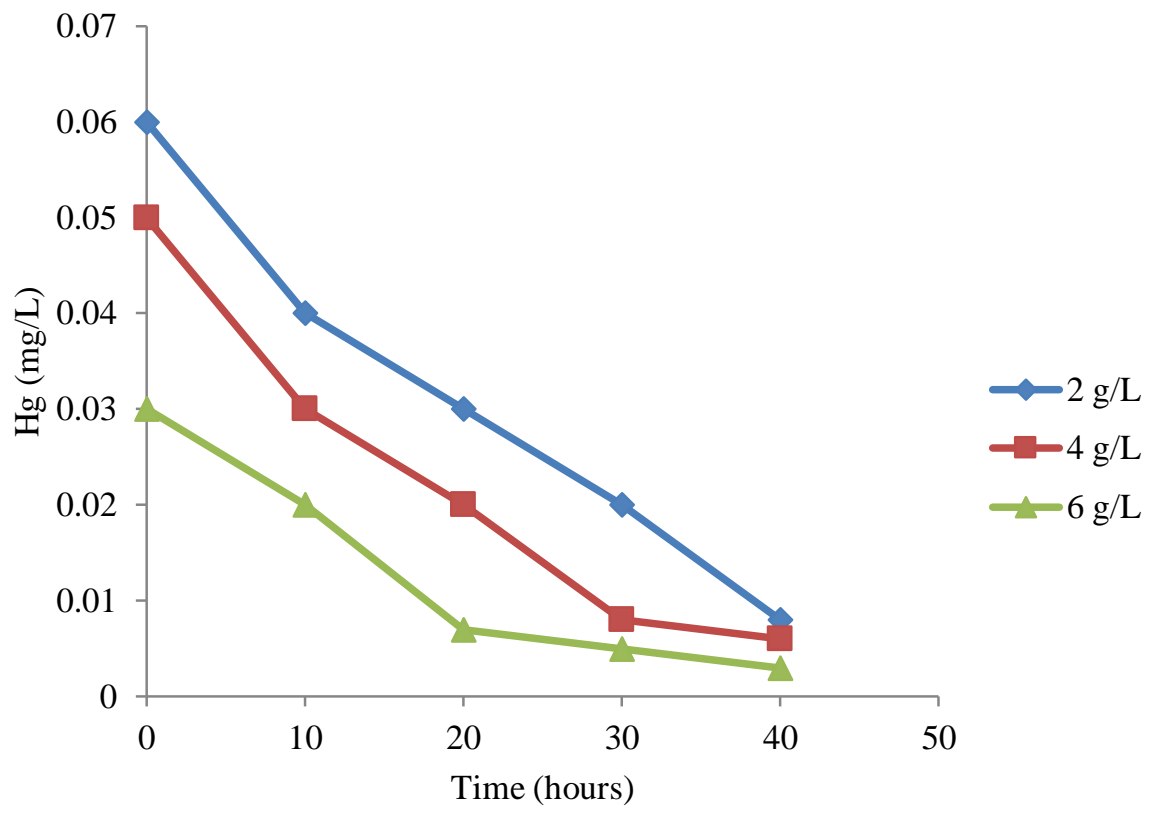

Figure 4. Effect of Varying Bio Char Concentration at Constant $\mathrm{pH}$ 


\subsubsection{Adsorption Removal Efficiency at Varying Bio Char Loading}

The adsorption efficiency decreased with increase in the adsorption time of up to 40 hours (Figure 5). The highest adsorption efficiency was observed at a loading of $6 \mathrm{~g} / \mathrm{L}$ and this trend was attributed to the high mercury capture by the bio char at high loading.

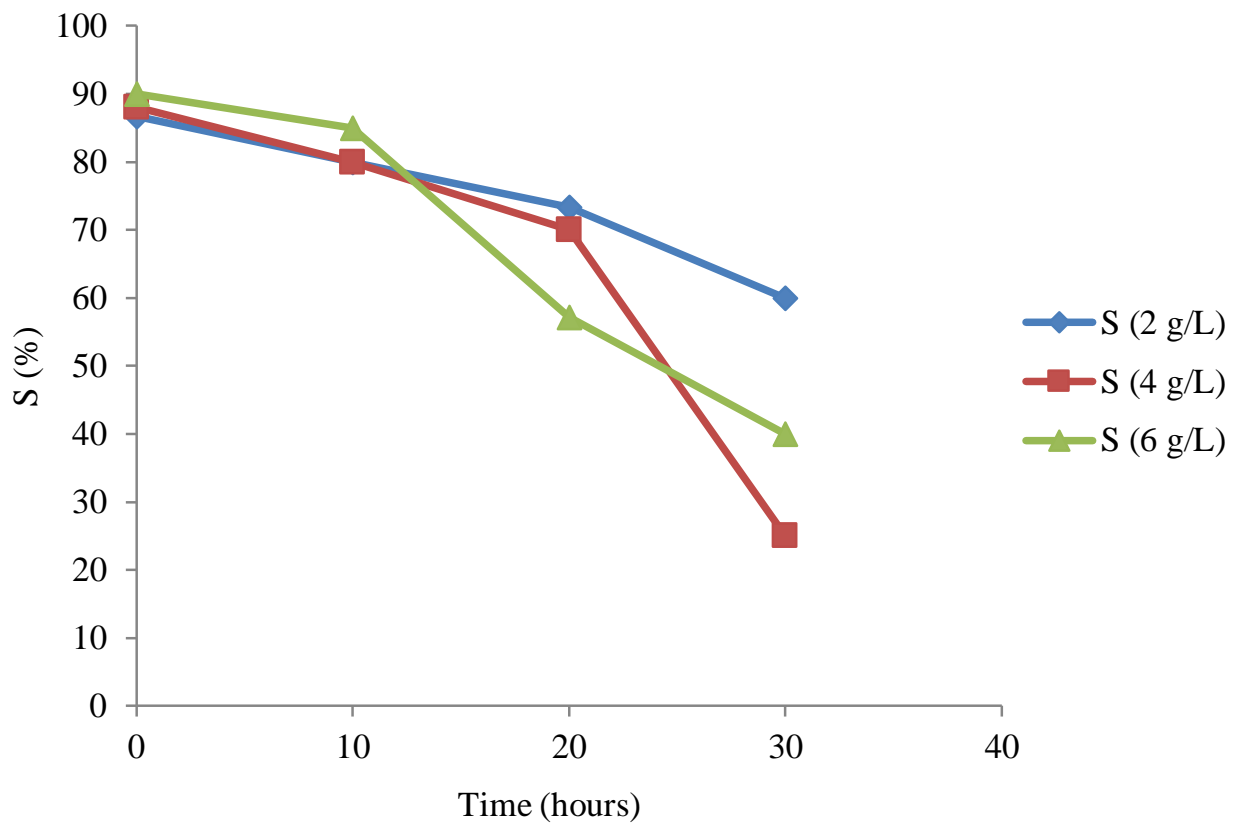

Figure 5. Adsorption Removal Efficiency at Varying Bio Char Loading

\section{CONCLUSION}

Bio char from saw dust provides a good raw material for bio adsorbents with good properties for application in gold mining wastewater treatment with mercury as the target contaminant. Mercury concentrations were significantly reduced to less than $0.004 \mathrm{mg} / \mathrm{L}$ for bio char loading of $6 \mathrm{~g} / \mathrm{L}$ at a $\mathrm{pH}$ of 8 . The adsorption efficiency was as high as $90 \%$ and was dependent on the adsorption time, bio char loading and $\mathrm{pH}$ of wastewater. The treated wastewater can be safely disposed of to water bodies due to the low mercury content obtained. The application of saw dust as a biomass derived bio adsorbents provides both a low cost solution for gild tailings wastewater treatment and also a waste management solution for saw dust from the timber milling industry.

\section{REFERENCES}

APHA, Standard Methods for the Examination of Water and Wastewater. 21st Edition, American Public Health Association/American Water Works Association/Water Environment Federation, Washington DC, 2005.

Arana, J., González, S., Navarrete, L., Caicedo, O., 2017. Luffa Cylindrica as a natural adsorbent of cyanide ion in aqueous medium, DYNA, vol. 84, no. 201, pp. 210-215.

Babel, S., Kurniawan, T. A., 2003. Low-cost adsorbents for heavy metals uptake from contaminated water: A Review, Journal of Hazardous Materials, vol. B97, pp. 219-243.

Beesley, L., MorenoJimenez, E., Fellet, G., Carrijo, L. and Sizmur, T.,2015. Biochar and heavy metals. In: Lehmann, J. and Joseph, S. (eds.) Bio char for environmental management: science, technology and implementation. 2nd ed. Earth scan, London, pp. 563594. ISBN 9780415704151 Available at http://centaur.reading.ac.uk/40801/, 2015. 
Gupta, V. K., Rastogi, A., Nayak, A., 2010. Biosorption of nickel onto treated alga (Oedogonium hatei): Application of isotherm and kinetic models, Journal of Colloid and Interface Science, vol. 342, pp. 533-539.

Khan, N. A., Ali, S. I., Ayub, S., 2001. Effect of pH on the removal of chromium (Cr) (VI) by sugar cane bagasse, Sultan Qaboos University Journal for Science, vol. 6, pp. 13-19.

Kumar, D., Gaur, J. P., 2011. Metal bio sorption by two cyanobacterial mats in relation to pH, biomass concentration, pre-treatment and reuse, Bioresource Technology, vol. 102, no. 3, pp. 2529-2535.

Matshusa K., Ogola J.S., Maas K. Dispersion of metals at Louis Moore gold tailings dam, Limpopo province, South Africa; Proceedings of the International Mine Water Association Symposium; Bunbury, Australia. 30 September 2012; pp. 334A-334E.

Tripathi, A., Ranjan, M. R., 2015. Heavy Metal Removal from Wastewater Using Low Cost Adsorbents, Journal of Biodegradation and Bioremediation, vol. 6, pp. 315.

Veiga, M. M., Maxson, P. A., Hylander, L. D., Origin and consumption of mercury in small-scale gold mining, Journal of Cleaner Production, vol. 14, pp. 436-447, 2006.

Vinodhini, V., Das, N., Vinodhini, V., Das, N., 2010. Relevant approach to assess the performance of sawdust as adsorbent of chromium (VI) ions from aqueous solutions, International Journal of Environmental Science and Technology, vol. 7, pp. 85-92.

Wong, K. K., Lee, C. K., Low, K. S., Haron, M. J., 2003. Removal of $\mathrm{Cu}$ and $\mathrm{Pb}$ by tartaric acid modified rice husk from aqueous solution, Chemosphere, vol. 50, pp. 23-28. 